\title{
Høyspenningsskade i hodet
}
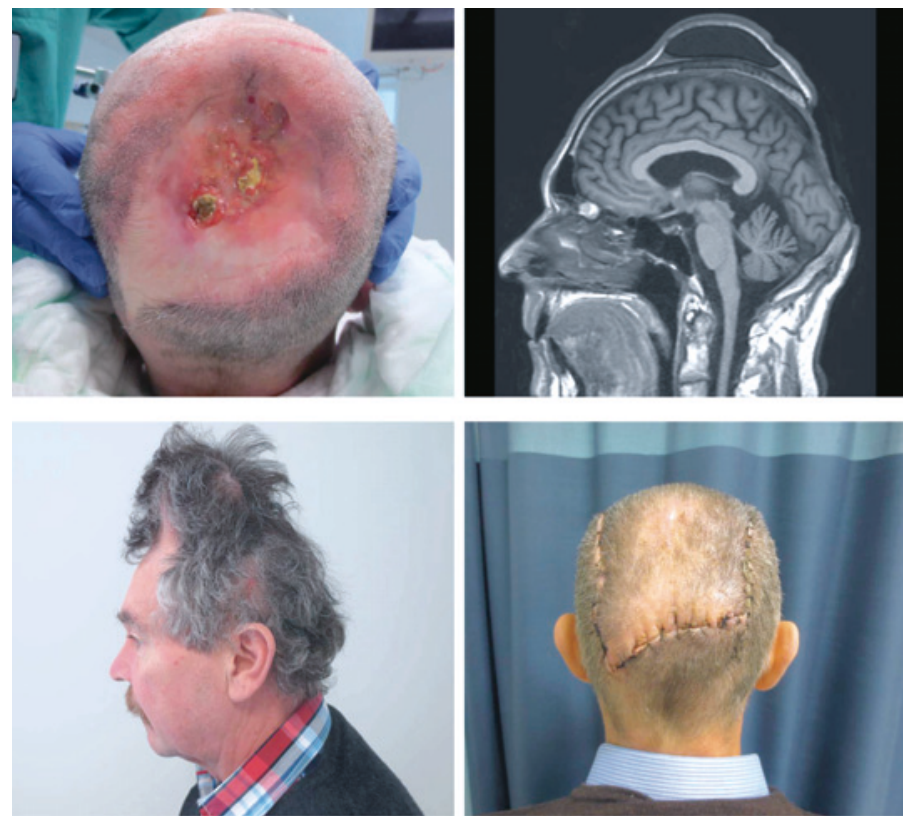

Foto: Kjersti Ausen

En mann som nå er i 60-årene ble for nærmere 40 år siden utsatt for en høyspenningsskade da han sto på en lastebil og fikk bakhodet $i$ en høyspentledning. Han fikk en større hud- og beindefekt i skallen parietooksipitalt. Planlagt plastikkirurgisk rekonstruksjon fant ikke sted, da plastikkirurgen på behandlingsstedet gikk av med pensjon. Imidlertid epitelialiserte såret spontant, og tross beindefekten levde han bra med arret og beindefekten inntil det aktuelle. Han hadde selv fått tilvirket en hard beskyttende plastskive med pålimt hår som kamuflerte og beskyttet det tynne arret $i$ det daglige og hadde ikke oppsøkt hjelp for å få kirurgisk korreksjon etter tilhelingen.

I forbindelse med langvarig antibiotikabehandling etter en hoftefraktur med påfølgende infeksjon utviklet han spontant en ulcerasjon $\mathrm{i}$ den tynne huden parietooksipitalt (bildet øverst til venstre), og han fikk samtidig hodepine. Sårdanning og hodepine forverret seg gradvis over noen måneder, og han ble innlagt på nevrologisk avdeling. Under den aktuelle innleggelsen ble han blant annet utredet med cerebral MR som viste en beindefekt i kraniet på $6 \times 7 \mathrm{~cm}$, mens det underliggende hjerneparenkymet var upåfallende. Imidlertid var det kun et marginalt sjikt mellom ulcerasjonen og hjernen. På grunn av økende utbredelse og væsking fra det kroniske såret ble det funnet indikasjon for kirurgisk behandling. Biopsier fra ulcerasjonene hadde ikke vist tegn til malignitet som kan oppstå etter kroniske sår og brannskader (1).
Man besluttet å legge inn en vevsekspander mellom galea og periosteum, som over de neste månedene ble ekspandert med ca. $500 \mathrm{ml}$ saltvann (bildene øverst til høyre og nederst til venstre). I denne perioden gikk ulcerasjonen - og da også hodepinen - spontant tilbake. Ved avsluttet ekspansjon etter fem måneder hadde man tilstrekkelig vev til å kunne transponere frem en hårbærende fullhudslapp (bildet nederst til høyre). Man deepitelialiserte det gamle arret uten perforasjon av dura. Kraniedefekten består, og pasienten er anbefalt å bruke sin gamle tilvirkede eksterne beskytter i risikosituasjoner.

Vevsekspansjon av hud ble beskrevet allerede i 1950-årene (2) og brukes av plastikkirurger for dekking av ulike huddefekter. Metoden kan brukes ved brystrekonstruksjon, fjerning av arr, dekking av ulike defekter i hud og underliggende vev, f.eks. sekveler etter brannskade, infeksjon, traume eller kirurgi (3-5). Metoden er særlig nyttig i hårbærende områder. Hårtransplantasjon er da ofte ikke nødvendig.

Pasienten har gitt samtykke til at artikkelen blir publisert.

\section{Clemens Weber}

clemens.weber@ntnu.no

Nevrokirurgisk avdeling

St. Olavs hospital

og

Institutt for nevromedisin

Norges teknisk-naturvitenskapelige universitet
Kjersti Ausen

Avdeling for plastikkirurgi

St. Olavs hospital

Clemens Weber (f. 1979) er konstituert overlege og ph.d.-student.

Forfatter har fylt ut ICMJE-skjemaet og oppgir ingen interessekonflikter.

Kjersti Ausen (f. 1971) er overlege.

Forfatter har fylt ut ICMJE-skjemaet og oppgir ingen interessekonflikter.

\section{Litteratur}

1. Kowal-Vern A, Criswell BK. Burn scar neoplasms: a literature review and statistical analysis. Burns 2005; 31: 403-13

2. Neumann CG. The expansion of an area of skin by progressive distention of a subcutaneous balloon use of the method for securing skin for subtotal reconstruction of the ear. Plast Reconstr Surg (1946) 1957; 19: 124-30

3. Argenta LC, Watanabe MJ, Grabb WC. The use of tissue expansion in head and neck reconstruction. Ann Plast Surg 1983: 11:31-7.

4. Di Mascio D, Castagnetti F, Mazzeo F et al. Overexpansion technique in burn scar management. Burns 2006; 32: 490-8.

5. Namba RS, Diao E. Tissue expansion for staged reimplantation of infected total knee arthroplasty. J Arthroplasty 1997; 12: 471-4. 